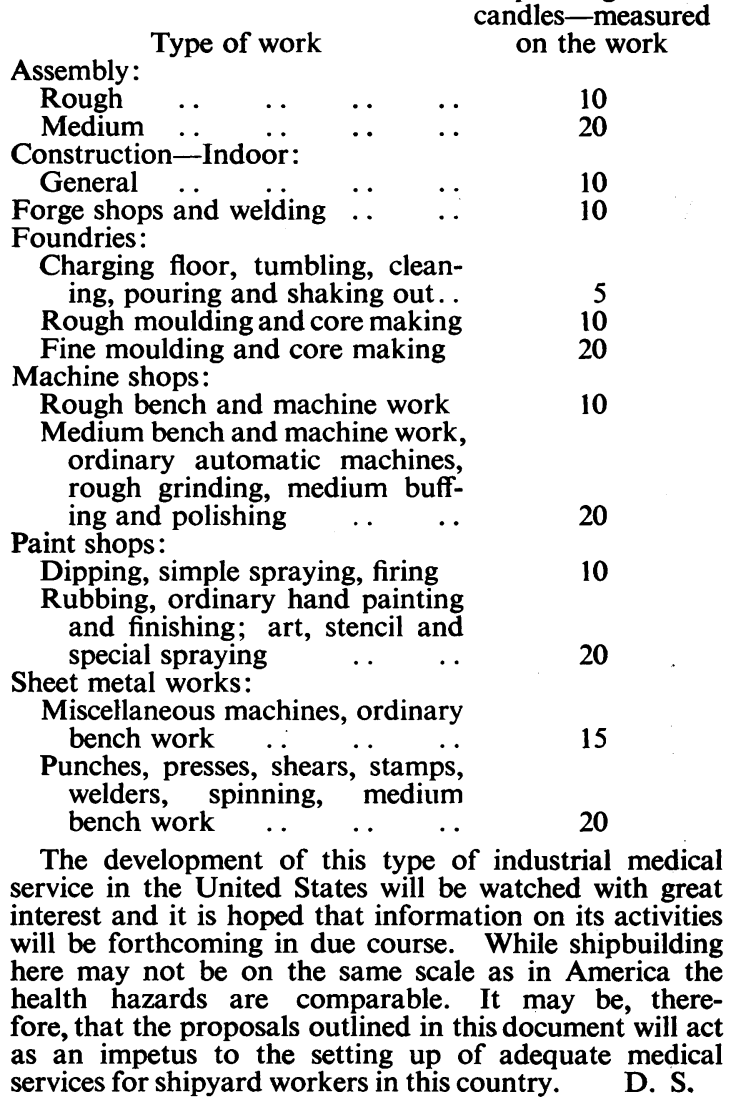

\section{YOUNG CITIZEN}

By A. E. Morgan

(Penguin Books, Hermondsworth, Middlesex, 1943. Pp. 192. 9d.)

In 1938 the author made a survey of the adolescent 'citizens in the country, on behalf of King George's Jubilee Trust. This Penguin restates in shortened form the results of that survey and refers also to certain factual developments since war broke out.

In 1937 there were approximately $3 \frac{1}{4}$ million boys and girls in the age-group 14-18. It was then predicted that a falling birth rate would reduce this by one-fifth in 10 years, and by one-third, or over $\frac{3}{4}$ million, in 20 years. Had it not been for the war the school-leaving age would have been raised in September, 1939, from 14 to 15 . In January, 1941, the President of the Board of Education declared that he accepted the principle of raising it eventually to 16 . Only thus can we adequately educate the youth of Great Britain. Day Continuation Schools, with compulsory part-time attendance up to 18 for those not full-time at school, is another requisite. Attendance must take place in the employer's time in the case of those at work, and not during leisure hours.

On leaving school at present the usual procedure is for the boy and girl to seek work. This is an immense event for a lad. The work is likely to be much harder than at school, but it is a worth-while price for what seems to be freedom. To be able to buy cigarettes and spit, and to cheek the foreman (at least once). The problem is to find the right job. It can be met by opening up the blind alley, by adequate training methods, and by proper placement. Apprenticeship or learnership schemes include study at a Technical College, and the employer may give time off for this. Unfortunately these schemes at present affect only a small proportion of juveniles. In Coventry, for example, there were before the war about 8,500 boys between 14 and 18 . The engineering industry employed nearly 6000 . Over the 5 years up to 1937 the average number of apprentices gaining certificates under the training scheme was 63 annually.

In discussing health and welfare the author states that the physical condition of juveniles is far from what it should and could be, although height and weight, general health and teeth have all improved, partly from remedial measures but mainly because of advances in social and economic conditions and education. The doctor, dentist and nurse can do little if good housing, food, light, air and clothing are lacking. Nutrition is a question basically affecting youth. The conditions under which young wage-earners work are important. The main reform is shortening working hours. It should not be permissible, for example, for boys to work in mines. In 1936 over 47,000 boys under 18 worked below ground. Accidents to young workers had risen, especially in coalmining. Provisions to be ensured include hot mid-day meals at reasonable cost, supply of milk when it becomes again possible, adequate sleep, improvement in personal habits and dress, facilities for recreation, more adequate medical care after leaving school including dental and other benefits, medical inspection under the Factories Act to include adequate follow-up, and a fuller understanding of the particular requirements of youth.

The book also includes well-documented and interesting chapters on unemployment, public protection, delinquency, boys' and girls' organizations, leadership, conduct and religion, and finally outlines objectives for the future. In view of the vital importance of juvenile health in industry, and the fact that it must therefore be one of the foremost responsibilities of doctors and nurses in the factory, this book is at once an authoritative document and a fascinating subject for study.

\section{VENTILATION AND HEATING: LIGHTING AND SEEING}

Industrial Health Research Board Pamphlet No. 1

(H.M. Stationery Office. 1943. Pp. 20. 3d.)

During the war there has been much evidence that the results of research into industrial health are still not widely enough known and applied. This pamphlet, the first of a new series published by the Industrial Health Research Board, is intended to meet the apparent need for brief and easily understandable accounts, in nontechnical language, of the findings of research workers. The pamphlet is intended primarily for laymen, including nurses, personnel and welfare officers, works managers and engineers, and for the workers themselves. However, many members of the medical profession also will find that it provides useful information about the effects of working conditions on the health of the workers.

One striking example of the importance of good ventilation and heating is given by the record of accidents in munition factories in the war of 1914-18. Accidents were at a minimum when the shop temperature was between $65^{\circ}$ and $70^{\circ} \mathrm{F}$., and increased by as much as 30 per cent when the temperature fell below $55^{\circ}$ and by 20 per cent. when it rose above $75^{\circ}$. In some factories there is still very inadequate ventilation during the blackout, and suggestions are made for remedying this, and thus diminishing the risk of the spread of infection and feelings of fatigue.

Good general illumination of a factory stimulates production by causing workers to feel more cheerful and energetic, and also permits safe and rapid movement of persons and materials about the factory and makes cleaning easier. Fine work may need up to 100 times more light than the roughest work, and the value is stressed of measuring light by the simple light-meter. In addition, special spectacles may be needed, prescribed by an expert who, of course, must take into consideration the nature of the work as well as the vision of the worker. Much 